\title{
Corporate Social Responsibility and Firm Performance:
}

\section{Evidence from an Emerging Market}

\author{
Elif Akben Selcuk ${ }^{1} \&$ Halil Kiymaz ${ }^{2}$ \\ ${ }^{1}$ Department of Business Administration, Kadir Has University, Istanbul, TURKEY \\ ${ }^{2}$ Crummer Graduate School of Business, Rollins College, Winter Park, FL, USA. \\ Correspondence: Halil Kiymaz, Crummer Graduate School of Business, Rollins College, 1000 Holt Avenue-2722, \\ Winter Park, FL 32789, USA.
}

Received: May 15, 2017

Accepted: August 23, 2017

Online Published: September 7, 2017

doi:10.5430/afr.v6n4p42

URL: https://doi.org/10.5430/afr.v6n4p42

\begin{abstract}
This study focuses on the relationship between firm performance and corporate social responsibility (CSR) of firms listed on Borsa Istanbul during the period of 2009-2011. We use content analysis of annual reports/websites of Turkish firms for any socially responsible activities. We find a negative relationship between CSR and financial performance, meaning that firms which disclose more information about CSR initiatives in their annual reports have a lower return on assets. After controlling for debt and size of the firms, we further find that while highly levered firms are less profitable, larger firms have higher profits. Finally, we do not find any significant relationships between research and development expenditures and financial performance.
\end{abstract}

\section{JEL Classification:}

Keywords: Corporate social responsibility, Emerging markets, Firm performance

\section{Introduction}

The fundamental goal of a business firm, especially a corporation, is to maximize shareholder wealth as reflected in the market price of the firm's stock. Achieving this goal assumes that managers operate in the best interests of stockholders, avoid actions designed to deceive financial markets to boost the firm's stock price, and act in a socially responsible manner. So, shareholder wealth maximization is consistent with the best interest of stakeholders and society in the long run. However, it is unclear how corporate socially responsible finance aligns with the shareholder wealth maximization. In today's business environment, companies are increasingly faced with a demand for more attention to corporate social responsibility (CSR) initiatives, from the part of several non-shareholding stakeholders including customers, employees or NGOs (Michelon, Boesso, and Kumar (2013). Even though most companies accept the need to conduct CSR activities to establish better relationships with stakeholders, a question which arises is whether these initiatives lead to better financial performance.

Socially responsible finance includes responsibility from the corporate side (corporate social responsibility) as well as the investor side (socially responsible investing) in the capital markets. On the corporate side, as the consumers become more aware of corporate activities, some corporations decided to embark on CSR programs designed to offset some of their effects on the world while also generally improving corporate practices. CSR is the decision-making and implementation process that guides all company activities in protecting and promoting labor and environmental standards, and compliance with legal requirements within its operations. CSR involves a commitment to contribute to the economic, environmental, and social sustainability of communities. Socially responsible investing (SRI), on the other hand, is ethical investing and green investing that is considered socially responsible because of the nature of the business the company conducts.

The relationship between a firm's CRS and its financial performance has been debated since the 1960s without consensus by the academic community. A clear evidence of a relationship or lack of it is an important issue for management. If socially responsible activities add value to the firm, then firms may be encouraged to pursue such activities. Although the link between CSR and financial performance has been a central topic of research for more than three decades, the majority of the studies in the literature have been conducted for developed economies rather than developing countries. However, the need for CSR initiatives is stronger in the developing world since there are 
fewer institutions to provide social goods and there is a demand from the companies to fill these gaps (Dobers and Halme (2009)).

The focus of this research is to investigate the relationship between firm performance and CRS. Our approach focuses on the content analysis of annual reports/websites of Turkish firms during the period of 2009-201 for any socially responsible activities. Our study contributes to the literature in the following ways. First, we provide evidence for a fast-growing emerging market on the social responsibility awareness of the firms. Second, we use of content analysis which has the advantage of being objective as the results are independent of the particular research. On the other hand, the choice of variables to measure is subjective. Further, content analysis is a report of what firms say they are doing, and not necessarily what they are doing. Finally, we further examine the impact of CSR disclosure level on financial performance using various proxies for financial performance.

We find a negative relationship between corporate social responsibility disclosure (CSRD) and financial performance, meaning that firms which disclose more information about CSR initiatives in their annual reports have a lower return on assets. When we control for size, capital structure, and R\&D expenditure among other variables. We find return measures are directly related to the size of the firm, inversely related to leverage.

The remaining of the study is organized as followings. The next section reviews the literature on SRS and firm performances for developed as well as emerging markets. Then we report data selection, model, and statistical summaries. The empirical findings are reported in Section 4. We conclude the paper in the last section.

\section{Literature Review}

The literature contains mixed results on the relationship between corporate social and corporate financial performance. Theoretically, the neoclassical theory suggests a negative effect of firms' CSR practices on their financial performance because socially responsible companies face additional costs (Bird, Hall, Momente, and Reggiani (2007)). On the contrary, the stakeholder theory suggests that companies should engage in good relationships with all stakeholders (Freeman (2004)). Hence, socially responsible companies are expected to obtain greater financial returns through indirect effects such as the recruitment of more qualified employees (Greening and Turban (2000)) or building moral capital (Godfrey (2005)).

Empirically, many studies investigated the relationship between corporate social responsibility initiatives and financial performance. Although studies conducted on developed country firms usually documented a positive relationship, there is also evidence to the contrary. For example, Cochran and Wood (1984) find firms with older assets have lower CRS ratings. Potential explanations for their findings include the fact that firms with older assets likely built their plants in a period when regulatory constraints were less severe. Another reason is firms with older assets being less flexible to adopt social changes. After controlling the age of assets, they provide weak evidence on the relationship between CSR and firm financial performance. On the other hand, Aupperle, Carroll, and Hatfield (1985) using a survey on administrated to corporate CEOs did not find any relationship between CSR and profitability. McGuire, Sundgren, and Schneeweis (1988) using Fortune magazine's ratings of corporate reputations show that a firm's prior performance is more closely related to CRS than is subsequent performance. They also report measures of risk are more closely associated with social responsibility than previous studies have suggested.

Griffin and Mohan (1997) emphasize the methodological inconsistencies in previous studies and use the five most commonly applied accounting measures in the corporate social performance and corporate financial performance literature to show that a priori use of measures may predetermine the CSR/CFP relationship outcome. Waddock and Graves (1997) find corporate social performance is positively associated with both past and future financial performance, supporting the theory that good management and CSP are positively related. McWilliams and Siegel (2000) argues that most of the studies investigating the impact of CSR on financial performance without taking into consideration the role of R\&D lead to upwardly biased estimates of the impact of CSR. The authors further note that to their empirical results, the impact of CSR on financial performance is a neutral one once firms' R\&D expenditures are accounted. Similarly, Orlitzky (2001) focus on the impact of size on the relationship between CRS and firm financial performance. The author does not confirm size as a third factor which would confound the relationship between CSR and firm performance but rather suggests that both small and large firms can benefit from CSR.

A meta-analysis by Peloza (2009) reviewed 128 empirical studies and reported that 59\% found a positive relationship between CSR and financial performance, $14 \%$ found a negative relationship and $27 \%$ found no relationship at all. In another meta-analytic study, Orlitzky, Schmidt, and Rynes (2003) report a positive relationship between CSR and financial outcomes, especially when reputation was used as a proxy for corporate social/ environmental responsibility. Similarly, Margolis and Elfenbein (2008) and Margolis, Elfenbein, and Walsh 
(2009) reviewed a large sample of 251 studies and concluded that the effect of CSR on financial performance is positive but small. Brammer and Millington (2008) use corporate social performance using corporate charitable giving as a proxy. Findings show that that firms with both unusually high and low CSP have higher financial performance than other firms, with unusually poor social performers doing best in the short run and unusually good social performers doing best over longer time horizons. Going one step further than the simple investigation of the link between CSR and financial performance, Hull and Rothenberg (2008) use additional variables, including innovation and level of differentiation as moderators of the link between financial performance and CSR. They document that the benefits of CSR are more pronounced for less innovative firms and those operating in industries with little differentiation. More recently, Wang and Choi (2013) find that not only the level but also the temporal and interdomain consistency of corporate financial performance have significant financial implications for companies using data from a sample of 622 companies, the authors. The authors further documented that consistency is most important for firms with high knowledge intensity.

There are also some studies examining the issue of CSR and financial performance in developing countries. Chapple and Moon (2005) investigate CRS in multiple Asian countries and report that that CSR does vary considerably among Asian countries but that this variation is not explained by development but by factors in the respective national business systems. It also concludes that multinational companies are more likely to adopt CSR than those operating solely in their home country. Chih, Chih, and Chen (2010) examine CSR and financial performance for a total of 520 financial firms in 34 countries, between the years 2003 and 2005. Findings show that firms with larger size are more CSR minded, and the financial performance and CSR are not related. Furthermore, financial firms in countries with stronger levels of legal enforcement tend to engage in more CSR activities, and those firms in countries with stronger shareholder rights tend to engage in less CSR activities.

In another focusing Asian emerging markets, Cheung, Tan, Ahn, and Zhang (2010) use the CSR scores issued by Credit Lyonnais for the period between 2001 and 2002. The authors document a positive relationship between the CSR practices of Asian companies and their market valuation. This positive relationship is also confirmed in several emerging market studies. For example, Saleh (2009) for Malaysia, Uadiale and Fagben (2012) for Nigeria, Choi and Jung (2008) for Korea, Mishra and Suar (2010) for India, and Yan, Lin and Chang (2010) for Taiwan. However, a negative relationship is also documented in other studies including those by Rahman, Zain, and Al-Haj (2011) for Malaysia and by Siregar and Bachtiar (2010) for Indonesia. Scholtens and Kang (2013) examine how earnings management is associated with CSR and investor protection with 139 firms in ten Asian countries. Findings show that Asian firms with relatively good CSR are engaged significantly less with earnings management. Investor protection also is negatively associated with earnings management. $\mathrm{Hu}$ and Scholtens (2014) investigate the corporate social responsibility (CSR) policies of commercial banks in 44 developing countries and report a positive and significant association between CSR policies and bank financial performance.

Studies focusing on CSR practices of Turkish firms are relatively few, mostly due to the lack of reliable scores. To develop a scale of CSR for Turkish firms, Turker (2009) uses data from 269 business professionals and identifies the four following dimensions of CSR: employees, customers, government and social stakeholders. In their descriptive study of the online communication practices of Turkish SMEs, Dincer and Dincer (2010) report that the number of SMEs disclosing their CSR practices is very low. In another study on Turkish firms, Ertuna and Tükel (2009) show, through content analysis, that traditional practices and market-driven local norms, rather than international factors affect CSR reporting.

In one of the few studies investigating CSR-financial performance relationship in Turkey, Aras, Aybars, and Kutlu (2010) analyze the companies in the ISE-100 index for the years 2005-2007 and document a positive relationship between CSR disclosure and firm size. However, no significant relationship between CSR and financial performance is reported. This finding is also confirmed by a more recent study of ISE-100 firms by Özçelik, Öztürk, and Gürsakal (2015). On the other hand, using a smaller sample of 28 firms belonging to ISE Corporate Governance index, Arsoy, Arabaci and Çiftçioğlu (2012) find a positive relationship between CSR scores derived from content analysis and accounting based financial performance indicators. So, the evidence on the financial performance and CRS of Turkish firms are mixed at best. Our study provides additional evidence using a more recent and extended data.

\section{Methodology}

\subsection{Data and Variables}

To investigate the relationship between corporate social responsibility disclosure and financial performance in Turkey, we collect data on firms listed on Borsa Istanbul from January 2009 to December 2011. The sample consists 
of 341 firms per year and a total of 1,023 firm-years of observations. Data on financial performance and firm-specific characteristics are obtained from Finnet database.

To measure corporate social responsibility, we employ the content analysis method on the companies' annual reports as suggested by Hughes, Anderson, and Golden (2001). Corporate social responsibility is analyzed based on seven distinct dimensions: environment, energy, consumer, community involvement, employee health and safety, other employee-related issues, and general (Aras, Aybars, and Kutlu (2010)). We use three units for our analysis: the number of sentences devoted to CSR on the annual report, the number of pages related to CSR, and the number of the CSR dimensions mentioned based on the seven categories. Based on these units of analysis, three different CSR disclosure (CSRD) measures are defined: The first measure is related to the depth of CSRD and is calculated as the total number of sentences the company devotes to the seven CSR dimensions in its annual report. We also calculate a second CSRD measure defined as the total number of pages devoted to CSR, instead of the number of sentences. CSR breadth, on the other hand, is defined as the number of CSR dimensions that the company refers to in its annual report.

Return on assets (ROA) is used as a dependent variable for this study to measure the potential benefits that companies could get from their CSR activities. We also include several control variables that might affect a company's financial performance. First, we include the variable SIZE defined as the natural logarithm of the firm's total sales. LIQUIDITY is measured by the firm's current ratio calculated as the ratio of its current assets divided by its current liabilities. RISK is proxied by the beta coefficient. The variable $R \& D$ refers to the research and development expenditures divided by net sales $I N T$ is a dummy which takes the value of 1 for firms which derive some of their revenues from international sales and 0 otherwise. LEVERAGE is measured by the ratio of total interest-bearing debt to total assets while the variable GROWTH refers to the percentage change in net sales compared to the previous year.

\subsection{Estimation}

Three different versions of the following equation will be used, each using one of the three measures of CSRD introduced in the previous section. Panel regressions with robust standard errors will be estimated to assess the relationship between CSRD and financial performance. To control for industry-specific effects that might affect financial performance, we include industry dummies in the regression models. We prefer a stepwise approach where control variables are incorporated one by one into the model.

$$
R O A_{i t}=\beta_{0}+\beta_{1} \operatorname{CSRD}_{i t}+\beta_{2} X_{i t}+\varepsilon_{i t}
$$

where:

$R O A_{i t}$ is the return on assets for firm $i$ in year $t$,

$C S R D_{i t}$ is one of the three corporate social responsibility disclosure measures for firm $i$ in year $t$,

$X_{i t}$ is the set of control variables for firm $i$ in year $\mathrm{t}$,

$\beta_{0,} \beta_{1}$, and $\beta_{2}$ are vectors of parameters to be estimated,

$\varepsilon_{i t}$ is the error term.

\section{Empirical Results}

\subsection{Statistics on CSR Disclosure}

Table 1 reports the CSR disclosures made by firms in our sample for during the study period. The table shows the companies making at least one CSR disclosure in their annual reports. The number of companies making at least one CSR disclosure in any of the categories increased from 208 in 2009 to 253 in 2011. The maximum number of disclosures was recorded in the general CSR category with 240 companies in 2009 followed by environment category with 235 disclosures while the minimum was observed in the energy category with 50 companies in the year 2009. The average number of CSR dimensions that companies mention in their annual reports are equal to 2.63, 2.65 and 2.85 for the years 2009,2010 , and 2011 respectively. 
Table 1. CSR Disclosure in the Turkish Companies' Annual Reports

This reports the distribution of firms with CSR disclosures during the study period 2009-2011.

\begin{tabular}{|c|c|c|c|c|c|c|}
\hline & \multicolumn{2}{|c|}{2011} & \multicolumn{2}{|c|}{2010} & \multicolumn{2}{|c|}{2009} \\
\hline & $\mathbf{n}$ & $\%$ & $\mathbf{n}$ & $\%$ & $\mathbf{n}$ & $\%$ \\
\hline Environment & 235 & 0.69 & 212 & 0.62 & 197 & 0.58 \\
\hline Energy & 59 & 0.17 & 53 & 0.16 & 50 & 0.15 \\
\hline Consumer & 79 & 0.23 & 71 & 0.21 & 70 & 0.21 \\
\hline Community & 103 & 0.30 & 91 & 0.27 & 97 & 0.28 \\
\hline Employee health and safety & 67 & 0.20 & 59 & 0.17 & 56 & 0.16 \\
\hline Employee, other & 185 & 0.54 & 153 & 0.45 & 147 & 0.43 \\
\hline General & 240 & 0.70 & 212 & 0.62 & 194 & 0.57 \\
\hline Total & 253 & 0.74 & 228 & 0.67 & 208 & 0.61 \\
\hline
\end{tabular}

$\mathrm{n}=$ number of companies making at least one disclosure in each category

$\%=$ number of companies making at least one disclosure in each category as a percentage of total sample $(\mathrm{n}=341)$

Table 2 and Table 3 contain the descriptive statistics on CSR based on the number of sentences and the number of pages respectively. The average number of sentences devoted to CSR in the Turkish companies annual reports increased from approximately 30.63 sentences in 2009 to 38.65 sentences in 2001. Similarly, the average number of pages increased from 3.17 in 2009 to 3.88 in 2001.

Table 2. Number of Sentences Devoted to CSR

This table reports the summary statistics related to the number of sentences devoted to CSR in annual reports

\begin{tabular}{lllllllll} 
2011 & Env. & Energy & Cons. & Community & Health & $\begin{array}{l}\text { Emp. } \\
\text { Other }\end{array}$ & General & Total \\
\hline Mean & 6.36 & 2.44 & 3.16 & 5.98 & 2.90 & 7.19 & 16.41 & 38.65 \\
Median & 4 & 0 & 0 & 0 & 0 & 5 & 17 & 27 \\
Min & 0 & 0 & 0 & 0 & 0 & 0 & 0 & 0 \\
Max & 127 & 65 & 78 & 112 & 97 & 75 & 124 & 597 \\
StDev & 10.19 & 7.48 & 8.99 & 15.17 & 8.61 & 9.59 & 15.12 & 60.12 \\
Range & 127 & 65 & 78 & 112 & 97 & 75 & 124 & 597 \\
2010 & Env. & Energy & Cons. & Community & Health & Other & General & Total \\
\hline Mean & 6.67 & 2.34 & 3.10 & 5.57 & 2.51 & 6.42 & 15.35 & 34.45 \\
Median & 3 & 0 & 0 & 0 & 0 & 0 & 17 & 23 \\
Min & 0 & 0 & 0 & 0 & 0 & 0 & 0 & 0 \\
Max & 90 & 65 & 90 & 121 & 39 & 75 & 124 & 476 \\
StDev & 10.06 & 7.34 & 9.36 & 14.53 & 6.62 & 9.51 & 14.89 & 55.08 \\
Range & 90 & 65 & 90 & 121 & 39 & 75 & 124 & 476 \\
2009 & Env. & Energy & Cons. & Community & Health & Other & General & Total \\
\hline Mean & 6.04 & 2.17 & 3.11 & 5.39 & 2.44 & 6.01 & 13.73 & 30.63 \\
Median & 3 & 0 & 0 & 0 & 0 & 0 & 14 & 17 \\
Min & 0 & 0 & 0 & 0 & 0 & 0 & 0 & 0 \\
Max & 110 & 65 & 90 & 121 & 39 & 75 & 111 & 521 \\
StDev & 9.86 & 6.95 & 9.11 & 13.44 & 6.53 & 8.95 & 13.60 & 52.71 \\
Range & 110 & 65 & 90 & 121 & 39 & 75 & 111 & 521 \\
\hline
\end{tabular}


We further report the number of sentences related to various sub-topics. These include environment, energy, consumer, community, health, employee-related, and general. The maximum average number of sentences (16.41) and pages (1.52) is recorded in the general category in 2011. This category is followed by the other employee-related issues dimension averaging 7.19 sentences and 0.50 pages in 2011. The minimum amount of CSR disclosure is in the energy category.

Overall, we find that every sub-category experiences increase in their disclosure during the study period. Both the number of sentences devoted to CSR and the number of pages reported to CSR increases. This would suggest that Turkish firms are becoming more aware of the demand for more attention to corporate

Table 3. Number of Pages Devoted to CSR

This table outlines the summary statistics of number pages reported to CSR

\begin{tabular}{lllllllll} 
2011 & \multicolumn{1}{c}{ Env. } & Energy & Cons. & Community & Health & $\begin{array}{l}\text { Emp. } \\
\text { Other }\end{array}$ & General & Total \\
\hline Mean & 0.52 & 0.27 & 0.29 & 0.46 & 0.25 & 0.50 & 1.52 & 3.88 \\
Median & 0 & 0 & 0 & 0 & 0 & 0 & 1 & 2 \\
Min & 0 & 0 & 0 & 0 & 0 & 0 & 0 & 0 \\
Max & 6 & 6 & 9 & 9 & 6 & 5 & 8 & 40 \\
StDev & 0.93 & 0.82 & 0.99 & 1.43 & 0.82 & 0.93 & 1.46 & 5.95 \\
Range & 6 & 6 & 9 & 9 & 6 & 5 & 8 & 40 \\
2010 & Env. & Energy & Cons. & Community & Health & Other & General & Total \\
\hline Mean & 0.46 & 0.22 & 0.28 & 0.41 & 0.24 & 0.47 & 1.33 & 3.41 \\
Median & 0 & 0 & 0 & 0 & 0 & 0 & 1 & 2 \\
Min & 0 & 0 & 0 & 0 & 0 & 0 & 0 & 0 \\
Max & 6 & 6 & 6 & 7 & 6 & 4 & 7 & 36 \\
StDev & 0.87 & 0.72 & 0.92 & 1.18 & 0.80 & 0.89 & 1.33 & 5.33 \\
Range & 6 & 6 & 6 & 7 & 6 & 4 & 7 & 36 \\
2009 & Env. & Energy & Cons. & Community & Health & Emp. & & Other \\
\hline Mean & 0.43 & 0.21 & 0.27 & 0.37 & 0.20 & 0.41 & 1.25 & 3.17 \\
Median & 0 & 0 & 0 & 0 & 0 & 0 & 1 & 2 \\
Min & 0 & 0 & 0 & 0 & 0 & 0 & 0 & 0 \\
Max & 7 & 7 & 8 & 7 & 6 & 4 & 8 & 37 \\
StDev & 0.84 & 0.81 & 0.95 & 1.07 & 0.69 & 0.78 & 1.33 & 5.11 \\
Range & 7 & 7 & 8 & 7 & 6 & 4 & 8 & 37 \\
\hline
\end{tabular}

social responsibility (CSR) initiatives and responding to these demands. These findings are in line with the view of Michelon, Boesso, and Kumar (2013). Even though most companies accept the need to conduct CSR activities to establish better relationships with stakeholders, a question which arises is whether these initiatives lead to better financial performance.

\subsection{Descriptive Statistics of Regression Variables}

Table 4 reports the descriptive statistics of regression variables. As indicated before, we use ROA as the dependent variable for this study. We also include several control variables that might affect a company's financial performance. First, we include the variable SIZE defined as the natural logarithm of the firm's total sales. The average SIZE variable is 19.049 with a minimum of 14.115 and a maximum of 25.741. LIQUIDITY is measured by the firm's current ratio calculated as the ratio of its current assets divided by its current liabilities. The average liability for this firm is below one. This variable RISK is proxied by the beta coefficient with an average value of 0.671 . The variable $R \& D$ refers to the research and development expenditures divided by net sales and average is 0.05 with the lowest 
standard deviation. INT is a dummy which takes the value of 1 for firms which derive some of their revenues from international sales and 0 otherwise. LEVERAGE is measured by the ratio of total interest-bearing debt to total assets while the variable GROWTH refers to the percentage change in net sales compared to the previous year. Average leverage is 0.481 while the average growth rate is 14.7 percent.

Table 4. Descriptive Statistics

This table provides the descriptive statistics of variables used in regression analysis.

\begin{tabular}{llllll} 
Variable & Obs & Mean & Std. Dev. & Min & Max \\
\hline ROA & 1023 & 0.026 & 0.192 & -4.452 & 1.005 \\
CSR depth (sentences) & 1023 & 39.695 & 58.373 & 0 & 597 \\
CSR depth (pages) & 1023 & 3.485 & 5.435 & 0 & 40 \\
CSR breadth & 1153 & 2.654 & 2.158 & 0 & 7 \\
SIZE & 1023 & 19.049 & 1.894 & 14.115 & 25.741 \\
LIQUIDITY & 1023 & 0.867 & 1.254 & 0.005 & 16.967 \\
LEVERAGE & 1023 & 0.481 & 0.596 & 0 & 12.563 \\
R\&D & 1023 & 0.005 & 0.032 & 0 & 0.634 \\
GROWTH & 962 & 0.147 & 1.441 & -1 & 26.2 \\
INT & 1023 & 0.587 & 0.493 & 0 & 1 \\
RISK & 1002 & 0.671 & 0.216 & -0.122 & 1.221 \\
\hline
\end{tabular}

\subsection{Regression Results}

Table 5 below contains results for stepwise regression analysis. In each of the cases, the Hausman specification test points to a violation of the assumptions of the random effects model, therefore we prefer fixed effects. In columns 1 to 7 of Table 5, we introduce the control variables to investigate their impact on ROA.

In the first column, we measure the impact of SIZE, measured as the natural log of sales, on profitability. The coefficient is 0.012 and statistically significant at 1 percent level. This indicates that there is a positive relationship between size and firm profitability, larger firms experience higher profits. In the following columns, we add LIQUIDITY, LEVERAGE, R\&D, GROWTH, INT, and RISK variables into the analysis respectively. Three of the variables, SIZE, LIQUIDITY, and GROWTH have a positive relationship with firm profitability. While the coefficients of first two are statistically significant at 1 percent level, GROWTH is weakly significant at 5 percent level. LEVERAGE and RISK variables, on the other hand, are inversely related to the profitability, and their coefficients are statistically significant at 1 percent level. Firms with higher leverage and higher beta coefficients experience a lower return on assets. Finally, $R \& D$ variable does have any significant relationship with profitability.

In the last three columns of Table 5, we report the relationship between CSR disclosure and the financial performance of firms while including control variables. First, the signs and significance of the control variables remain the same when CSR measures are introduced into the models. We used three different CSR disclosure (CSRD) measures: The first measure is related to the depth of CSRD and is calculated as the total number of sentences the company devotes to the seven CSR dimensions in its annual report. The second CSRD measure defined as the total number of pages devoted to CSR, instead of the number of sentences. CSR breadth, on the other hand, is defined as the number of CSR dimensions that the company refers to in its annual report.

Our findings show that CSR depth measured by the number of pages is inversely related to our profit measure of ROA. The finding is statistically significant at $5 \%$ level with $\mathrm{R}^{2}$ of 0.24 . When we use CSR depth (Sentences) instead of CSR depth (pages), we find similar results. CSR depth (sentence) variable still has negative coefficient and is statistically significant at $5 \%$ with an $\mathrm{R}^{2}$ value of 0.26 . Other control variables remain statistically significant. Finally, when we use the number of dimensions referred in the company annual report (CSR breadth) as our independent variable, we continue to have a mildly significant coefficient.

So regardless of the CSRD measure we employ, we find a negative relationship between CSRD and financial performance, meaning that firms which disclose more information about CSR initiatives in their annual reports have a lower return on assets. McGuire, Sundgren, and Schneeweis (1988), Rahman, Zain, and Al-Haj (2011), Siregar and Bachtiar (2010), and Walley and Whitehead (1994), among others, also report similar findings. 
Table 5. CSRD and Financial Performance

This table provides the results of stepwise regression analysis using ROA as the dependent variable.

\begin{tabular}{|c|c|c|c|c|c|c|c|c|c|c|}
\hline & Step 1 & Step 2 & Step 3 & Step 4 & Step 5 & Step 6 & Step 7 & Step 8 & Step 9 & Step 10 \\
\hline Constant & $\begin{array}{l}-0.216^{* 0 *} \\
(-3.50)\end{array}$ & $\begin{array}{l}-0.243^{* * *} \\
(-2.43)\end{array}$ & $\begin{array}{l}-0.161^{* * *} \\
(-3.86)\end{array}$ & $\begin{array}{l}-0.165^{n+*} \\
(-3.92)\end{array}$ & $\begin{array}{l}-0.170^{\text {knt }} \\
(-4.04)\end{array}$ & $\begin{array}{l}-0.176^{* 0 *} \\
(-4.73)\end{array}$ & $\begin{array}{l}-0.160^{\text {t+ }} \\
(-4.03)\end{array}$ & $\begin{array}{l}-0.183^{* * t} \\
(-4.10)\end{array}$ & $\begin{array}{l}-0.252^{* 0 *} \\
(-5.20)\end{array}$ & $\begin{array}{l}-0.161^{\text {*.*. }} \\
(-4.05)\end{array}$ \\
\hline SIZE & $\begin{array}{l}0.012^{* * *} \\
(3.96)\end{array}$ & $\begin{array}{l}0.014^{* * *} \\
(4.37)\end{array}$ & $\begin{array}{l}0.012^{* * *} \\
(5.06)\end{array}$ & $\begin{array}{l}0.012^{* * *} \\
(5.11)\end{array}$ & $\begin{array}{l}0.013^{* * *} \\
(5.33)\end{array}$ & $\begin{array}{l}0.017^{* * *} \\
(7.96)\end{array}$ & $\begin{array}{l}0.016^{* * *} \\
(7.31)\end{array}$ & $\begin{array}{l}0.018^{* * * * *} \\
(6.95)\end{array}$ & $\begin{array}{l}0.022^{* * *} \\
(7.85)\end{array}$ & $\begin{array}{l}0.017^{* * 3} \\
(7,07)\end{array}$ \\
\hline LIQ & & $\begin{array}{l}0.009^{* *} \\
(2.48)\end{array}$ & $\begin{array}{l}0.008^{* * *} \\
(2.91)\end{array}$ & $\begin{array}{l}0.008^{* * 8} \\
(2.94)\end{array}$ & $\begin{array}{l}0.0007^{4 * 4 *} \\
(2.69)\end{array}$ & $\begin{array}{l}0.0077^{* k 4} \\
(2.91)\end{array}$ & $\begin{array}{l}0.007^{* * 4} \\
(2.70)\end{array}$ & $\begin{array}{l}0.006^{* * 4} \\
(2.87)\end{array}$ & $\begin{array}{l}0.008^{* * *} \\
(2.98)\end{array}$ & $\begin{array}{l}0.008^{* * 3} \\
(3,01)\end{array}$ \\
\hline RISK & & & $\begin{array}{l}-0.054^{* 44} \\
(-2.63)\end{array}$ & $\begin{array}{l}-0.055^{*+*} \\
(-2.67)\end{array}$ & $\begin{array}{l}-0.054^{4 * 4} \\
(-2.63)\end{array}$ & $\begin{array}{l}=0.086^{* 4 *} \\
(-4.73)\end{array}$ & $\begin{array}{l}-0.092^{4 * *} \\
(-4.75)\end{array}$ & $\begin{array}{l}-0.094^{* * 6} \\
(-4.79)\end{array}$ & $\begin{array}{l}-0.098^{444} \\
(-4.93)\end{array}$ & $\begin{array}{l}-0.093^{4+4} \\
(-3.76)\end{array}$ \\
\hline R\&D & & & & $\begin{array}{l}0.110 \\
(0.87)\end{array}$ & $\begin{array}{l}0.102 \\
(0.82)\end{array}$ & $\begin{array}{l}0.062 \\
(0.56)\end{array}$ & $\begin{array}{l}0.064 \\
(0.57)\end{array}$ & $\begin{array}{l}0.064 \\
(0.57)\end{array}$ & $\begin{array}{l}0.024 \\
(0.21)\end{array}$ & $\begin{array}{l}0.065 \\
(0.57)\end{array}$ \\
\hline INT & & & & & $\begin{array}{l}0.034^{* * *} \\
(2.70)\end{array}$ & $\begin{array}{l}0.035^{* * *} \\
(2.71)\end{array}$ & $\begin{array}{l}0.032^{* * *} \\
(2.70)\end{array}$ & $\begin{array}{l}0.033^{* * *} \\
(2.72)\end{array}$ & $\begin{array}{l}0.033^{* * *} \\
(2.70)\end{array}$ & $\begin{array}{l}0.032^{* * *} \\
(2.70)\end{array}$ \\
\hline LEV & & & & & & $\begin{array}{l}-0.134^{2 * 2} \\
(-16.34)\end{array}$ & $\begin{array}{l}-0.137^{2 * *} \\
(-16.07)\end{array}$ & $\begin{array}{l}-0.138 * * z \\
(-16.10)\end{array}$ & $\begin{array}{l}-0.138^{46 *} \\
(-16.24)\end{array}$ & $\begin{array}{l}-0.138 * * * \\
(-16.03)\end{array}$ \\
\hline GROWTH & & & & & & & $\begin{array}{l}0.037^{4} \\
(1.87)\end{array}$ & $\begin{array}{l}0.042^{4} \\
(1.88)\end{array}$ & $\begin{array}{l}0.042^{*} \\
(1.82)\end{array}$ & $\begin{array}{l}0.041^{*} \\
(1.79)\end{array}$ \\
\hline CSR depth (pages) & & & & & & & & $\begin{array}{l}-0.121^{* *} \\
(-2.22)\end{array}$ & & \\
\hline CSR depth (sentences) & & & & & & & & & $\begin{array}{l}-0.012^{* *} \\
(-2.28)\end{array}$ & \\
\hline CSR breadth & & & & & & & & & & $\begin{array}{l}-0.031^{*} \\
(-1.71)\end{array}$ \\
\hline $\mathrm{R}^{2}$ & 0.015 & 0.041 & 0.060 & 0.061 & 0.094 & 0.158 & 0.221 & 0.242 & 0.262 & 0.242 \\
\hline $\mathrm{N}$ & 1023 & 1023 & 1002 & 1002 & 1002 & 1002 & 947 & 947 & 947 & 947 \\
\hline F-statistic & $15.64^{* * t}$ & $10.93^{* 06}$ & $10.34 * * *$ & $17.95^{* 2 *}$ & $16.94^{\text {*ै* }}$ & $51.83^{* * 4}$ & $42.68^{* * *}$ & $37.51 * 06$ & $39.40^{* * *}$ & $37.33^{* * *}$ \\
\hline
\end{tabular}

$* * *, * *$, and $*$ denote significance on $1 \%, 5 \%$ and $10 \%$ respectively. t-statistics are reported in parentheses.

\section{Conclusion and Discussion}

The relationship between a firm's CRS and its financial performance has been getting the attention of both academics and practitioners. A clear evidence of a relationship or lack of it is an important issue for management. If socially responsible activities add value to the firm, the firm may be encouraged to pursue such activities.

The focus of this paper is to investigate the relationship between firm performance and CRS. Our approach focuses on the content analysis of annual reports/websites of Turkish firms during the period of 2009-2011 for any socially responsible activities. The use of content analysis has the advantage of being objective as the results are independent of the particular research. We use three different CSR disclosure (CSRD) measures: the depth of CSRD (the total number of sentences the company devotes to the seven CSR dimensions in its annual report), depth of CSRD (the total number of pages devoted to CSR), and CSRD breadth (the number of CSR dimensions that the company refers to in its annual report).

Our findings show a negative relationship between CSRD variables and financial performance, meaning that firms which disclose more information about CSR initiatives in their annual reports have a lower return on assets. The findings remain the same whether CSR is analyzed using either variation of depth or breadth. While these findings are inconsistent with the findings reported for developed markets, it is line with and is consistent with several other studies (e.g., McGuire et al. 1988; Rahman et al., 2011; Siregar and Bachtiar 2010; Walley and Whitehead 1994). These findings imply socially responsible activities may not be value adding activities for Turkish firms that may be encouraged to pursue such activities more selectively.

Finally, our step regression analysis show that larger and more liquid firms have higher profitability than smaller and less liquid firms. Highly levered firms and firms with higher beta coefficients, on the other hand, experience lower profitability. Finally, research and development expenditures do not have a significant relationship with profitability. 


\section{References}

Aras, Guler, Asli Aybars, \& Özlem Kutlu. (2010). Managing corporate performance: Investigating the relationship between corporate social responsibility and financial performance in emerging markets. International Journal of Productivity and Performance Management, 59, 229-256. https://doi.org/10.1108/17410401011023573

Arsoy, Aylin Poroy, Özer Arabaci, \& Aydem Çiftçioğlu. (2012). Corporate social responsibility and financial performance relationship: The case of turkey. Kurumsal Sosyal Sorumluluk ve Firma Performansı Arasindaki İlişki : Türkiye Örneği. 159-176.

Aupperle, Kenneth E., Archie B. Carroll, \& John D. Hatfield. (1985). An empirical examination of the relationship between corporate social responsibility and profitability. Academy of Management Journal, 28, 446-463. https://doi.org/10.2307/256210

Bird, Ron, Anthony D. Hall, Francesco Momentè, \& Francesco Reggiani. (2007). What corporate social responsibility activities are valued by the market?, (Springer Science \& Business Media B.V.).

Brammer, Stephen, \& Andrew Millington. (2008). Does it pay to be different? An analysis of the relationship between corporate social and financial performance. Strategic Management Journal, 29, 1325-1343. https://doi.org/10.1002/smj.714

Chapple, Wendy, \& Jeremy Moon. (2005). Corporate social responsibility (csr) in Asia: A seven-country study of csr web site reporting. Business \& Society, 44, 415-441. https://doi.org/10.1177/0007650305281658

Cheung, Yan, Weiqiang Tan, Hee-Joon Ahn, \& Zheng Zhang. (2010). Does corporate social responsibility matter in asian emerging markets? Journal of Business Ethics, 92, 401-413. https://doi.org/10.1007/s10551-009-0164-3

Chih, Hsiang-Lin, Hsiang-Hsuan Chih, \& Tzu-Yin Chen. (2010). On the determinants of corporate social responsibility: International evidence on the financial industry. Journal of Business Ethics, 93, 115-135. https://doi.org/10.1007/s10551-009-0186-x

Choi, Tae, \& Jinchul Jung. (2008). Ethical commitment, financial performance, and valuation: An empirical investigation of korean companies. Journal of Business Ethics, 81, 447-463. https://doi.org/10.1007/s10551-007-9506-1

Cochran, Philip L., \& Robert A. Wood. (1984). Corporate social responsibility and financial performance. Academy of Management Journal, 27, 42-56. https://doi.org/10.2307/255956

Dincer, C., \& B. Dincer. (2010). An investigation of turkish small and medium - sized enterprises online csr communication. Social Responsibility Journal, 6, 197-208. https://doi.org/10.1108/17471111011051711

Dobers, Peter, \& Minna Halme. (2009). Corporate social responsibility and developing countries. Corporate Social Responsibility \& Environmental Management, 16, 237-249. https://doi.org/10.1002/csr.212

Ertuna, Bengi, \& Ali Tükel. (2009). Turkiye'de kss uygulamalari ve kursel arasinda. CSR PRACTICES IN TURKEY: IN BETWEEN TRADITIONAL AND GLOBAL, 9, 145-172.

Freeman, R. Edward. (2004). The stakeholder approach revisited. Zeitschrift fuer Wirtschafts- und Unternehmensethik, 5, 228-241.

Godfrey, Paul C. (2005). The relationship between corporate philanthropy and shareholder wealth. Academy of Management Review, 30, 777-799. https://doi.org/10.5465/AMR.2005.18378878

Greening, Daniel W., \& Daniel B. Turban. (2000). Corporate social performance as a competitive advantage in attracting a quality workforce. Business \& Society, 39, 254-280. https://doi.org/10.1177/000765030003900302

Griffin, Jennifer J., \& John F. Mahon. (1997). The corporate social performance and corporate financial performance debate: Twenty-five years of incomparable research. Business and Society, 36, 5-31. https://doi.org/10.1177/000765039703600102

Hu, Vi-in, \& Bert Scholtens. (2014). Corporate social responsibility policies of commercial banks in developing countries. Sustainable Development, 22, 276-288.

Hughes, S.B., A. Anderson, \& S. Golden. (2001). Corporate environmental disclosure: Are they useful in determining environmental performance. Journal of Accounting and Public Policy, 20, 217-241. https://doi.org/10.1016/S0278-4254(01)00031-X

Hull, Clyde Eiríkur, \& Sandra Rothenberg. (2008). Firm performance: The interactions of corporate social performance with innovation and industry differentiation. Strategic Management Journal, 29, 781-789. 
https://doi.org/10.1002/smj.675

Margolis, Joshua D., \& Hillary Anger Elfenbein. (2008). Do well by doing good? Don't count on it. Harvard Business Review, 86, 19-20.

Margolis, Joshua D., Hillary Anger Elfenbein, \& James P. Walsh. (2009). Does it pay to be good...And does it matter? A meta-analysis of the relationship between corporate social and financial performance, https://doi.org/10.2139/ssrn.1866371

McGuire, Jean B., Alison Sundgren, \& Thomas Schneeweis. (1988). Corporate social responsibility and firm financial performance. Academy of Management Journal, 31, 854-872. https://doi.org/10.2307/256342

McWilliams, Abagail, \& Donald Siegel. (2000). Corporate social responsibility and financial performance: Correlation or misspecification? Strategic Management Journal, 21, 603-609. https://doi.org/10.1002/(SICI)1097-0266(200005)21:5<603::AID-SMJ101>3.0.CO;2-3

Michelon, Giovanna, Giacomo Boesso, \& Kamalesh Kumar. (2013). Examining the link between strategic corporate social responsibility and company performance: An analysis of the best corporate citizens. Corporate Social Responsibility \& Environmental Management, 20, 81-94. https://doi.org/10.1002/csr.1278

Mishra, Supriti, \& Damodar Suar. (2010). Does corporate social responsibility influence firm performance of indian companies? Journal of Business Ethics, 95, 571-601. https://doi.org/10.1007/s10551-010-0441-1

Orlitzky, Marc. (2001). Does firm size confound the relationship between corporate social performance and firm financial performance? Journal of Business Ethics, 33, 167-180. https://doi.org/10.1023/A:1017516826427

Orlitzky, Marc, Frank L. Schmidt, \& Sara L. Rynes. (2003). Corporate social and financial performance: A meta-analysis. Organization Studies (01708406), 24, 403-441. https://doi.org/10.1177/0170840603024003910

Özçelik, Funda, Burcu Avcı Öztürk, \& Sevda Gürsakal. (2015). Corporate sustainability: A research on firms that issue sustainability reports in turkey. Business \& Economics Research Journal, 6, 33-49.

Peloza, John. (2009). The challenge of measuring financial impacts from investments in corporate social performance. Journal of Management, 35, 22. https://doi.org/10.1177/0149206309335188

Rahman, N.H. , M. M. Zain, \& N.H.Y. Al-Haj. (2011). Csr disclosures and its determinants: Evidence from malaysian government link companies. Social Responsibility Journal, 7, 181-202. https://doi.org/10.1108/17471111111141486

Saleh, Mustaruddin. (2009). Corporate social responsibility disclosure in an emerging market: A longitudinal analysis approach. International Business Journal, 2, 131-142. https://doi.org/10.5539/ibr.v2n1p131

Scholtens, Bert, \& Feng-Ching Kang. (2013). Corporate social responsibility and earnings management: Evidence from asian economies. Corporate Social Responsibility \& Environmental Management, 20, 95-112. https://doi.org/10.1002/csr.1286

Siregar, S., \& Y. Bachtiar. (2010). Corporate social reporting: Empirical evidence from indonesia stock exchange. International Journal of Islamic and Middle Eastern Finance and Management, 3, 241-252. https://doi.org/10.1108/17538391011072435

Turker, Duygu. (2009). Measuring corporate social responsibility: A scale development study. Journal of Business Ethics, 85, 411-427. https://doi.org/10.1007/s10551-008-9780-6

Uadiale, Olayinka M., \& Temitope O. Fagben. (2012). Corporate social responsibility and financial performance in developing economies: The nigerian experience. Journal of Economics and Sustainable Development, 3, 44-57.

Waddock, Sandra A., \& Samuel B. Graves. (1997). The corporate social performance financial performance link. $\begin{array}{lllll}\text { Strategic Management } & \text { Journal, } & 18, & 303 .\end{array}$ https://doi.org/10.1002/(SICI)1097-0266(199704)18:4<303::AID-SMJ869>3.0.CO;2-G

Walley, Noah, \& Bradley Whitehead. (1994). It's not easy being green. Harvard Business Review, 72, 46-51.

Wang, Heli, \& Jaepil Choi. (2013). A new look at the corporate social-financial performance relationship the moderating roles of temporal and interdomain consistency in corporate social performance. Journal of Management, 29, 416-442. https://doi.org/10.1177/0149206310375850

Yang, Fu-Ju, Ching-Wen Lin, \& Yung-Ning Chang. (2010). The linkage between corporate social performance and corporate financial performance. African Journal of Business Management, 4, 406-414. 